\title{
Civilisations
}

Revue internationale d'anthropologie et de sciences

humaines

44 | 1997

Les peuples des forêts tropicales

\section{The human consequences of deforestation in the Moluccas}

\section{Roy Ellen}

\section{OpenEdition}

\section{Journals}

Electronic version

URL: http://journals.openedition.org/civilisations/1628

DOI: $10.4000 /$ civilisations. 1628

ISSN: 2032-0442

\section{Publisher}

Institut de sociologie de l'Université Libre de Bruxelles

\section{Printed version}

Date of publication: 1 January 1997

Number of pages: 176-193

ISBN: 2-87263-122-4

ISSN: 0009-8140

\section{Electronic reference}

Roy Ellen, «The human consequences of deforestation in the Moluccas », Civilisations [Online], 44 | 1997, Online since 29 June 2009, connection on 19 April 2019. URL : http:// journals.openedition.org/civilisations/1628; DOI : 10.4000/civilisations. 1628 


\section{THE HUMAN CONSEOUENCES}

OF DEFORESTATION IN THE MOLUCCAS

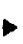

ROU ELLEN 


\section{INTROOUCTION}

Compared with other parts of island southeast Asia, little is known of either the forests of the Moluccas (map 1), of indigenous patterns of forest use, or of the threats posed to both forest and people by increasing rates of deforestation. In this paper I attempt to describe the effects of deforestation on the lives of the local population, using the small number of reports which are available. I begin by assessing the historical human impact on the forests of these islands, stressing both the varied patterns of sustainable accommodation reached between people and forest, and the fact that forest as presently constituted is the outcome of co-evolutionary processes of which humans themselves are an integral part. I then examine the main factors repeatedly cited as posing a danger to existing forest and forest peoples : swidden cultivation, plantation cropping, commercial logging and migratory land settlement. Using as an example the Nuaulu of Seram, I illustrate how these factors interact in a particular instance, as well as the various phases which typify a peoples exposure and response to, first, denudation, and then widespread degradation of the forest environment. I indicate that the phasing and character of these responses depend very much on local perceptions of government policy and on the extent to which policy is interpreted by officials and translated into action. The effects of policy vary between different parts of the Moluccas and different population groups, but I suggest that we can expect some convergence as the forested areas diminish in size.

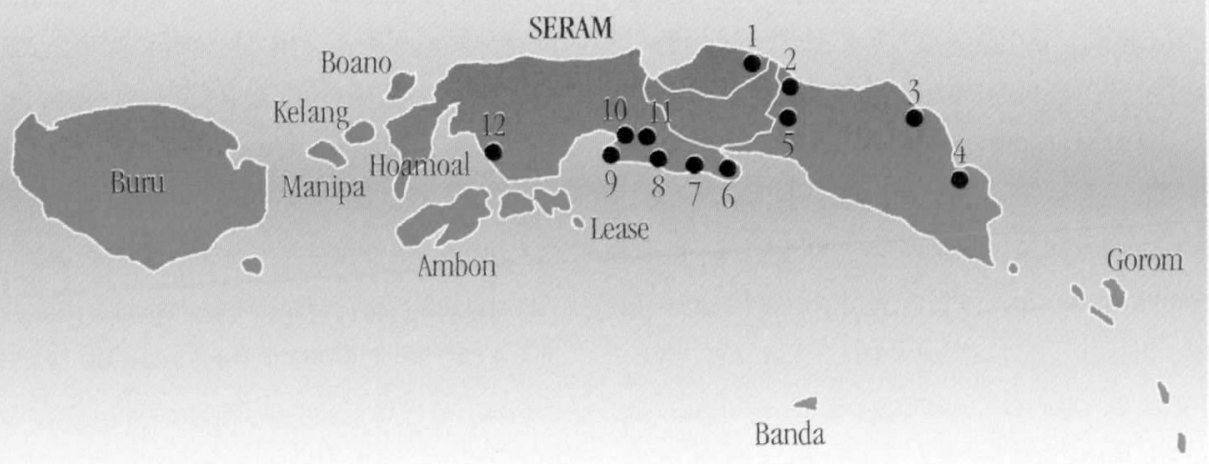

Map 1. The Moluccan islands of eastern Indonesia, illustrating principle places mentioned in the text. By the Moluccas, I understand here those islands lying within the boundary of the present-day Indonesian province of Maluku. The numbered locations are as follows: 1. Wahai; 2. Pasahari; 3. Bula; 4. Masiwang area; 5. Maneo and Seti; 6. Tehoru; 7. Tamilouw and Yalahatan; 8. Sepa area (includes villages of Rohua, Bunara, Watane, Hahuwalan, and formerly, Aihisuru); 9. Amahai; 10. Makariki; 11. Ruatan transmigration area (including Simalouw); 12. Kairatu. The area on Seram bounded by a thick line shows the position of the Manusela National Park. 


\section{HUMAN IMPACT ON THE FORESTS}

\section{OF THE MOLUCCAS BEFOAE 1900 OI)}

The ecology of insular southeast Asia has been dominated by rainforest for over 10,000 years, though it has changed much historically and is very varied geographically. One of the most immediately striking aspects of its variability is the significant decrease in Dipterocarp species as we move east and their replacement by dominants more typical of the Australo-Melanesian area. Thus, the forest biogeography of the Moluccas differs from that associated with the classic Dipterocarp forests, of say Borneo or Sumatra, in several features of its structure and composition, resembling much more Melanesia [Edwards et al, 1993; Edwards, 1993; Ellen, 1985:560-3]. It is this transitional (Wallacean) character that makes it of special interest. On Seram, for example, there are possibly just two species of Dipterocarp (Sborea selanica and one other), compared with 300 species on Borneo; there is just one Eucalypt (Eucalyptus deglupta) compared with 450 in Australia [Edwards, 1993 : 5]. In addition, although most of the primary lowland forest is of the moist evergreen type, displaying little seasonality, in places (most prominently, the west part of Yamdena and south Aru) we find semi-dry monsoon and savanna forest [SKEPHI, 1992 : 23; van Steenis, 1958], and patches of semi-evergreen forest on other islands (especially Halmahera, north Buru and Seram). Along the coasts there are some significant areas of mangrove (e.g. the Apu estuary on Buru, east and north Seram, Aru). In the low-lying valleys of the larger islands are extensive areas of Metroxylon (sagopalm) swamp forest, while montain forest is found on Buru and in upland central and west Seram. Indeed, from a scientific point of view, the Moluccas is one of the few places in the Indonesian archipelago where it is possible to find a complete altitudinal sequence of vegetation, and there are few places elsewhere in the tropics which provide a comparable range [Edwards, 1993:3]. Although there have been a few surveys on Halmahera and Seram, there has been relatively little quantitative study of Moluccan rainforest [Edwards et al, 1993:63].

There are, however, many ecological similarities between Moluccan forests and those further west in island southeast Asia. Not the least of these has been the role played by human populations. Forests have long been a focus of human subsistence extraction, and human agency has had decisive consequences for their ecology, for example, through the introduction and hunting of deer, the practice of small-scale swidden cultivation, the extraction of palm sago and selective logging and collection for exchange [Ellen, 1985, 1987]. The early history of Moluccan forests in human terms is poorly understood, with little empirical research which would shed direct light on the subject. From work elsewhere in insular southeast Asia, the evidence for human impact from 8000 BP onwards has been demonstrated, and although we would not expect this timedepth for the Moluccas, we should anticipate chronologies in terms of thousands rather than hundreds of years. The sub-fossil and palynological evidence in question usually comprises signs of anthropogenic burning and changing species composition reflecting patterns of clearance, cultivation and seed dispersal [Maloney, 1993]. No doubt similar data will eventually be forthcoming 
for the Moluccas, but despite prehistoric and historic modification, large tracts of Moluccan forest have remained more or less intact until relatively recently on the larger islands : that is on Halmahera, Seram, Buru, Yamdena and Sula. This has been due to low indigenous population levels, the concentration of the existing population in more accessible centres and along coasts, general economic peripherality and low in-migration.

At the present time, Moluccan populations exhibit a variety of subsistence strategies focused on differing degrees of forest modification and clearance. Though these patterns of extraction are often associated with separate types of people, linguistically, genetically and in terms of economy, the facts suggest that these distinctions are not hard and fast ones. At one end of the spectrum of techniques are peoples such as the Tugutil of central Halmahera who are engaged in nomadic hunting and gathering, but with some planting and reliance on trade [Martodirdjo, 1988: 15]. On Seram there is a wide variety of combinations of technique, ranging from mainly hunting and gathering with little cultivation (Huaulu, Maneo), through classic forms of swidden agriculture [Ellen, 1978], to more intensive forms of permanent ayriculture on the coast. The common characteristic of all these is the pivotal role played by the extraction of and dependence on sago [Ellen, 1979, 1988], which has the effect of minimizing the amount of rainforest cut. Crop regimes vary partly in relation to the contribution made by sago. Tuberous starch staples such as yams and taro have probably been important in many areas for thousands of years, and in some parts continue to be so. Grains have been historically significant elsewhere; dry rice in parts of Halmahera since around 1500, and formerly Coix, Cenchrus, millet (Setaria italica), and Sorghum [Visser, 1989]. Millet is also important in parts of the Kei islands, and Coix and dry rice on a small scale more widely [e.g. Ellen, 1973 : 460; Seran, 1922]. Musa (plantains and bananas) are grown almost everywhere. Since the seventeenth century, however, many of these cultigens have been outstripped in importance by introduced maize (particularly in the drier south), manioc (throughout, but especially on Kei), Xanthosoma (in wetter areas) and sweet potato. Rice is now grown more widely (particularly by migrants in both the northern and central Moluccas), and in irrigated fieids, but apparently not with a great deal of success.

Apart from the impact of these modes of subsistence, the main changes to Moluccan forest ecology that we can be sure of historically are associated with the growth of regional exchange systems linked to outside trade in forest products. Dammar or copal (Agalbis ckummara) resin has been extracted on Seram [Ormeling, 1947], Morotai [Riem, 1913 (1909)], Halmahera [Giel, 1935-6], Bacan [Kom, 1916], Obi [Ham, 1911] and elsewhere for centuries, and involves little destruction of trees. Traditional dammar tapping has recently declined and been replaced by commercial exploitation in some areas [Edwards, 1993: 8-9]. Much the same may be said for the oil of Melaleuca (cajupniti = leucodendron) on Buru and west Seram, reported as early as 1855 [Schmid, 1914; van der Crab, 1862], production of which, however, continues to rise [Kantor Statistik Provinsi Maluku, 1989]. of lesser importance are beeswax, kapok floss 
(Ceiba petandra), charcoal, and gaharu resin (poss. Aquilaria) used for incense and known to be collected in central Seram. But of the non-timber plant products, the most commercially important in bulk terms has been rattan [Kantor Statistik Provinsi Maluku, 1989]. Timber itself has been extracted for export from before European arrival, mainly for boatbuilding and fuel [Ellen, 1985, 1987: 40-1]. Forest has been additionally modified through introductions, both of domesticates and accidentals, through the deliberate planting of non-endemic non-domesticates, such as Tectona grandis [Ellen, 1987], and through the inadvertent dispersal of seeds from such useful trees as Canarium indicum. However, the most important single factor affecting Moluccan forests during the early period was the spice trade. Early extraction may reasonably be presumed to have been of non-domesticated varieties of clove and nutmeg, and wild nutmeg has continued to be of significance in some parts of the Moluccas and coastal Irian Jaya. The sustained and growing demand for spices, both in Europe and in Asia, led to the appearance of the domesticated varieties of commerce and their systematic planting in particular areas [Ellen, 1979] : clove first on Ternate, Tidore and latterly Seram, Ambon and the Lease islands, and nutmeg always focally on Banda, but less intensively elsewhere. The consequences of this development are taken up below.

The extraction of forest products for subsistence and trade increased during the Dutch period, from the early sixteen-hundreds onwards. In the first place this reflected Dutch pressure to monopolize and maximize spice production. However, with the decrease in demand for spices in the eighteenth century, the Moluccas became a commercial backwater, and this afforded some protection to its forests. The nineteenth century saw an upswing in the extraction of non-timber forest products for the European and Asian markets, and the first significant commercial logging activity on Seram [Ellen, 1985: 584]. It is reported that most of the forests of the Kei islands were clearfelled by a Dutch company in or before 1888 [SKEIHI, 1992 : 25].

\section{SWIDDEN CULTIVATION}

Despite repeated assertions to the contrary [e.g. Jones, 1976], forest-fallow swidden cultivation practised by indigenous populations is a productive use of forests, more so than commercial logging in terms of size of population supported; and on the whole it is ecologically efficient in its rapid recycling of regrowth. Indeed, it has been argued that the view of swidden agriculture as a destroyer of valuable resources and the creator of grass wastelands is simply a convenient ideology to legitimate commercial extraction in areas where the indigenous population has become an obstacle [Dove, 1983b : 195], or a justification for introducing large numbers of transmigrants with their supposedly more «advanced» sedentary systems [Potter, $1991: 188$ ]. One of the virtues of the term "swidden" is that it highlights the crucial difference between this kind of agricultural system and unplanned naive pioneer slash and burn, with which it is often confused.

Although Nuaulu in central Seram expressed a preference for cutting mature forest during the early nineteen-seventies [Dove, 1983a : 133], the 
amount cut during that period seldom exceeded 30 percent of forest cut in any one year [Ellen, 1978:83-4]. Overall, 90 percent of swidden land in use during the same period had been cut from secondary regrowth or bamboo scrub [Ellen, 1993a: 200]. This is high by comparative southeast Asian standards, but probably a consequence of recent population growth, and well within the parameters of what is sustainable. In addition, technical constraints on cutting (the use of axe and bushknife) have effectively restricted the amount of forest conversion for subsistence farming, leaving aside large trees such as Koompasia excelsa. Clearing for agriculture has in some areas (e.g around Wahai on Seram) left tracts of Imperata cylindrica [Fdwards, 1993: 8], sometimes with Melaleuca leucodendron, but in most cases grassland succession is either due to historic clearance for plantations, logging, or a result of reducing fallow periods as a means of intensifying agriculture to compensate for demographic stress. The incursions of non-indigenous settlers [Dove, 1983b : 90-3], entrepreneurial shifting cultivators, or what Secrett [Secrett, 1986] has appositely called «shifted" rather than shifting cultivators, are generally linked in the Moluccas to the expansion of transmigration settlement into surrounding areas, and the planting of cash crops [Dove, 1993: 19; Vayda, 1981]. There is no doubt that rapid forest conversation of this kind is damaging, and that long-standing sustainable practices are being eroded by technological innovation (e.g. chain-saws), population pressure and market forces, but the inevitable conclusion that all indigenous systems are to be discouraged is ignorant and counter-productive.

\section{PLANTATION CAOPPNA}

We have already noted that the establishment of nutmeg and clove groves occurred very early in Moluccan history. Even by the sixteenth century this had resulted in severe depletion of rainforest on the small spice-producing islands of Ternate, Tidore and Banda. Heavy denudation on small islands led to the development of zones of inter-island trade in which small islands became dependent on the forests of the larger islands for basic resources, such as sago, fuel, timber and thatch [Ellen, 1979]. The rise in international demand for spices led to the spread of production in the central Moluccas, and under the Dutch monopoly clove production was focused on Ambon-Lease, and native groves planted on the Hoamoal peninsula, western Seram and elsewhere extirpated [Ellen, $1987: 41-3$ ]. Nutmeg production after 1621 focused on the Banda islands under a Dutch settler regime. The demise of the Moluccan spice trade from the early eighteenth century onwards mitigated the ecological consequences of further clearance for plantations.

In the present century there has been renewed clearance : for clove, nutmeg and other tree crops, such as cocoanut, cacao and coffee, and

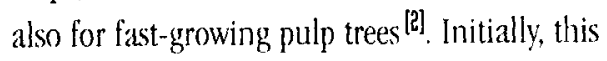
was in the form of small groves adjacent existing subsistence plots, and was sustainable in the context of an overall low-intensity agricultural regime. Indeed, groves continue to be intercropped with various swidden species. However, since the seventies, and with government encouragement, indigenous swiddeners, and late transmigrants, have cut increasingly large areas for plantations, by preference from primary forest [Ellen, 
1993b; Grzimek, 1992]. Up until the massive influx of transmigrants over the last decade or so, this expansion in cutting represented the main threat to forest. Commercial estate plantations have recently become important in some areas, such as on Seram (e.g. cacao in Wahai sub-district), on Halmahera (cinnamon) and on Yamdena, where the government has granted concessionees 30,000 hectares.

\section{COMMERCHLL LOGGING}

of the standing stock of major timber species in non-plantation forests throughout Indonesia only six percent is in the Moluccas, though this is probably to underestimate the timber potential. Indeed, Moluccan timber production has recently increased in importance [Potter, 1991 : 179]. In June 1989 there were 24 official forest concessions throughout the province, representing 2,593,000 hectares, the average size being 108,000 hectares. Only the Kalimantan provinces have more plywood factories and production capacity [ 1 bid.. $202,207]$.

Logging is a threat to forest and an indigenous way of life in a number of parts of the Moluccas, not least because forests contain good quality Shorea (meranti) [Edwards et. al. 1993 : 68]. What makes Moluccan forests more vulnerable is the small surface area of most of the islands. Already, islands as small as Taliabu and Mongole in the Sula group, and Morotai, Bacan, Obi, Kasiruta, Mandiuli around Halmahera have been opened-up to systematic felling. Even selective logging has heen shown to cause considerable damage. After 15 years forest in parts of north central Seram is still left with an open structure, much dead wood, serious gully erosion, soil compaction, herbaceous vegetation and extensive areas of secondary regrowth trees such as Macaronga. In this same area Sborea has been stripped from ridges, replaced by the invasive grass Imperata, leaving patches of mixed evergreen forest in the valleys [Edwards, 1993 : 9]. Logging is a particularly serious threat in the area where the Manusela National Park meets the Samal transmigration area, and failed transmigrants may move further into the forest [/bid., 11]. Logging roads in west Seram have opened-up the interior to further settlement by migrants and many transmigrants in the Pasahari area of north Seram rely on logging as their main source of income. Removal of forest (though not entirely because of logging) has also resulted in water shortages in some parts of the Wahai area, with knock-on health problems, and in seasonal flooding and water-shartages in the transmigration areas of Waihatu and Waimital in west Seram. Further east, south of Bula, in the area of the Masiwang river, local transmigration has followed logging and some replanting, mainly it would seem of cacao and some timber trees. Logging in this area continues.

On Yamdena logging is posing serious problems for biodiversity loss, threatening rare orchids such as Dendrobium plaluenopsis and several species of endemic bird. The most serious impacts, however, will be human, especially the effect on water supply. In 1992 logging roads alone had caused erosion in watershed areas and had contaminated streams with silt. Socially, disruption such as the destruction of sacred sites, has not been compensated for by employment pros- 
pects, the company recruiting only a few local people. The Association of Tanimbar Village Leaders has filed complaints to the local government [SKEPHI, 1992 : 24]. On Seram, timber extraction has heen perceived by some locals as having beneficial effects : discarded sawn timber and log ends are used as fuel and in manufacturing, lumber camp debris and leftover facilities provide a range of materials, while trackways serve to enhance hunting and communication [Ellen. 1985; Ellen, 1993b : 133]. It is likely, though, that the increasing scale of logging will modify the balance of advantages and disadvantages in the perceptions of local inhabitants (see below).

\section{POPULATIOH MOVEMENT AND TAAMSMIGRATION}

Population movement has probably been having an effect on patterns of deforestation in the Moluccas for as long as these islands have been inhabited by humans. In the case of the smaller islands this would account for their early depletion. Since 1600, however, we have clear evidence for deforestation through relocations within the same island, inter-island migration within the Moluccas and in-migration from without. The Moluccan-European wars of the seventeenth century resulted (as we have seen) in the extirpation of plantations, the wholesale depopulation of certain areas and the movement of populations elsewhere. For example, Collins [Collins 1980; 1984] has provided linguistic evidence for movements at this time which resulted in the setting-up at Nuelitetu, along the south Seram littoral, of a settlement of refugees from West Seram, speaking a Piru Bay (Wemale) language. During the nineteenth century Dutch administrative requirements to control fractious natives led to the emptying of large areas of the highlands and interiors of the main islands, in particular on Seram. This threatened forest in coastal areas but led to reduced hunting in the highlands. Reduced hunting increased animal density (particularly deer), with consequent severe browsing pressure [Edwards, 1993 : 10; Ellen, 1993a : 201]. Ironically, villagers in the central highlands of Seram now register a reduction in the availability of game animals, caused by disturbances to the edge of the Manusela National Park [Edwards, $1993: 11$ ].

For many centuries the Moluccas have additionally been the destination for migrants moving east from south and southeast Sulawesi : Buginese, and more recently, and in large numbers, Butonese. Over the last 15 years in-migration in certain areas has increased dramatically, partly through direct government-sponsored transmigration and partly through increased spontaneous migration made more attractive by new infrastructures such as roads, including those created in the first place for government transmigrants.

The Moluccas was first incorporated into the national transmigration programme ( Transmigrasi umum/nasional») as early as 1954, but was not an effective destination until the seventies. Between 1971 and 1980 there were 4,300 sponsored transmigrants settling in the Moluccas. This increased to 35,100 between 1980 and 1985 . Although only 2 percent of the total provincial population, they represented 17 percent of the population increase [Potter, $1991: 191]$. The greatest expansion took place between 1982 and 
1989, with 25,953 migrants from Java and other parts of the province settling special zones created on Seram (Pasahari and Banggaii) and Halmahera (Kao, Wasile and likor) [Kantor Statistik Kabupaten Maluku Tengah, 1984: 114; 1989 : 155]. Under the Fifth Five Year Plan (1987-91) rates of transmigration have increased further, and there are plans to resettle more. By 1992 there were 13 settlements all told, 3.1 percent of the provincial population : in excess of 23,042 transmigrants on Seram, 18,030 on Buru, 20,857 on Haalmahera and 174 on Aru, a total of 62,103 individuals [Goss, 1992 : 89-90]. There has been a tendency for family size to increase in recent years, and by 1994 transmigrants are likely to be 25 percent of the population of Aru, 20 percent of Buru, 7 percent of Halmahera and 8 percent of Seram [Ibid, p.91]. These figures do not, however, include spontaneous migrants who follow later, which the World Bank estimates are often more than double the number of official migrants [Donner, 1987 : 245].

It is generally reckoned that in Indonesia as a whole, transmigration and its knock-on effects have been more responsible than anything else for forest destruction, and certainly more damaging than either swidden cultivation or logging [Donner, $1987: 243$; Potter, $1991: 210$ ]. There is no reason to think that the situation in the Moluccas is any different. The damage is not simply that caused by initial clearance for new settlements, but results from few of the schemes being economically self-contained, often involving inappropriate farming models. To compensate, settlers extract from nearby forest, and seek to extend their land by slash-and-burn techniques, sometimes purchasing land from indigenous peoples where government authority permits (as in the case of the Nuaulu, see below), sometimes simply taking it. Where the Departments of Transmigration and Forestry have recognized the impracticality of wet rice cultivation, they have sometimes backed schemes dependent on industrial forest crops (Hutan Tanaman Industri). At present, as far as the Moluccas is concerned, this strategy appears only to have heen used on Buru [Goss, 1992 : 93]. The difficulty, though, is that tree crops require the clearance of larger areas of forest than for rice. At this point the problems posed by transmigration overlap with those already mentioned in relation to plantation cropping.

The consequences of transmigration for local peoples have been complex, but on the whole negative. Among the benefits cited are improved markets and services [Ibid., 95]. This is probably true for the south Seram area, where the influx of transmigrants has been accompanied by upgrading of roads and bus services, and has resulted in the development of local markets with new opportunities for sale of food products. Nuaulu cash incomes have increased, as we shall see, from the sale of land. Maneo villages also benefit from trade with transmigrants, through the provision of schools in transmigration areas and in the opportunities afforded to politically astute individuals. One of the main disadvantages, however, is that clearance interferes with the practice of indigenous patterns of subsistence. For example, hetween 1982 and 1985, 5000 hectares of forest cleared in central Halmahera for transmigration cut across pre-existing Tugutil zones of extraction and sago 
palms [Martodirdjo, 1988: 4]. Moreover, there is generally little recognition that the viability of indigenous sustainable swiddening requires a constant ratio of current gardens to forest fallow, and that therefore forest not being used by local farmers is not surplus to requirements. The government has in places expropriated disputed territory and not compensated owners [Goss, 1992 : 94]. The potential for conflict is considerable, and even where the indigenous population has in practice received certain legal protections (as among the Nuaulu), conflict with transmigrants has escalated to an alarming level.

In parts of Seram local peoples have spontaneously and voluntarily settled in transmigration areas (e.g. Maneo). Others have been assimilated willy-nilly as these areas have expanded to incorporate them (Seti), in some cases turning indigenous villages into «reservations» within larger environmentally-depleted and immigrant-dominated zones. In a number of places there have been attempts to incorporate local «tribal» peoples into transmigration schemes : on Buru [Goss, 1992 : 95], Seram LEllen, 1993b, and below] and Halmahera. The Halmahera scheme involved nomadic forest collectors (Tugutil) and was reportedly not a success [Martodirdjo, 1988 : $2,22]$. Incorporation of Nuaulu into the Ruatan scheme has been a mixed success : some Nuaulu have moved into the area permanently, some on a temporary basis; the scheme has provided good access to traditional areas of extraction, but led to conflict amongst Nuaulu, hetween Nuaulu and other indigenous peoples in the area, and between Nuaulu and settlers. We can now turn to this case and examine it in greater detail.

\section{THE NUAULUU CASE}

\section{Historical bachground}

The Nuaulu are an ethnic group of south Seram widely known in the central Moluccas for the tenacity and success with which they have clung to a traditional animist way of life. What distinguishes them from other similar groups is their demographic strength and the compromises they have historically made which have enhanced their survival as a discrete group. My own Nuaulu fieldwork has spanned the period 19701990, during which time important changes have taken place in terms of Nuaulu relationship with forest. However, there is no particular reason to assume that before 1970 significant changes were not already underway.

By the latter part of the nineteenth century Nuaulu inhabited dispersed patriclan hamlets on the southern side of the watershed of central Seram, focused on the Nua and Ruatan valleys. In this scheme of things, the term wasi referred to all cultivated clan-hamlet land, in contrast to wesie, uncut forest. It was not necessary to assert clan ownership of particular plots, since all territory was clan territory. But also, the idea of collectively identified Nuaulu territory, as opposed to the land of individual clans, remained no more than a vague abstraction until faced with the political realities imposed, first by the conditions of coastal settlement, and then by the Indonesian state in the nineteen-eighties. In the eighteeneighties Nuaulu began to settle around Sepa, a polity with which they have recorded traditional relations of amity going back to the seventeenth century. This led to changes in land tenure arrangements upon which I have already reported 
[Ellen, 1977; 1978: 81-107]. Here, I draw on this earlier work, and present only enough information to clarify the main issues being discussed.

\section{Land tenure circa 1970 : normative arrangements}

The clan Matoke is held to be primus inter pares with respect to many ritual matters, including those relating to the utilization of forest resources. The extent to which this was the case prior to 1880 is unclear, but it was a custom firmly embedded by the time Nuaulu clans were moving into the area of Sepa jurisdiction. The relationship which Matoke have with the land is perhaps best described as guardianship, though by 1970 this was routinely being translated into Ambonese Malay as "ownership" (puny'a, to possess; milik, property). The role is personified in the "lord of the land", the ia onate Matoke, who is ultimately responsible for the ritual supervision of Nuaulu relations with their environment. By 1970 day-to-day responsibility had been delegated to Matoke sub-clans (Matoke-hanaie in Niamonai, Matoke-pina in Rohua) and, in the case of the village of Bunara, to the clan Sonawe-aipura (in the person of the so-called ia onate Matoke Sonawe [Ellen, 1977: 57, n1.8]. The clan Matoke has no practical jurisdiction over gardens or plantations which are not regarded as traditional Nuaulu territory. If a domestic group or individual wishes to cut forest from an inland area over which it is generally agreed the Nuaulu have jurisdiction, authority must theoretically be sought from the ia onate Matoke, or his proxy. Although the Matoke headman may rule or advise that certain areas cannot be cultivated or extracted from, in practice the immediate authority is the head of the clan which claims the land as part of its own traditional territory. It is the head of this clan or his proxy who must be present when forest is first cut, in order to seek permission from the ancestors of the relevant clan, and to offer a compensatory sacrifice.

The cutting of mature forest (wesie) yields wasi, a term applied to all land which has been humanly-altered through clear-felling and over which direct (rather than residual) rights are maintained. The term may refer to cleared land in general or to individual jural units; to both a vegetational type and to a legal idea. Individual plots of wasi cultivated in any one year, or their productive ecological successors are known as nisi, which we may translate as «garden». Specific rights are thereby conferred, through the exercise of labour, on individuals, domestic groups, «houses" and clans who obtain access and use for as long as the claim is effectively perpetuated. The rights so conferred are serial, in that they are simultaneously individual, household, clan, or whatever; the level of emphasis depending wholly on context. Such land is inherited through the male line, though can be transferred between clans through marriage.

\section{Changes in land tenure. 1880-1970}

The above highly-compressed summary represents what we might regard as the «traditional» and normative arrangements as they existed in 1970. Since first concentrating on the coast important structural changes have been taking place. The factors involved can be grouped under five headings : 1. the creation of multi-clan settlements, 2. cash-cropping, 3. land scarcity, 4. sale 
of land, 5. and market individualism. All of them are discussed in detail in Ellen, 1977, and the issue of market individualism is taken further in Fillen, 1993b : 131. Here I mention just a few aspects for each heading :

1. with the congregation of the first clans on a confined area immediately to the west of Sepa, in what is now Nuaulu Lama (or, in Nuaulu, Niqmonai, «old village»), Nuaulu settlements forfeited their genealogical exclusiveness; formal kinship groups were no longer coterminus with local groups. Some attempt was made to assert clan autonomy through the establishment of separate settlements, first at Aihisuru, then Hahuwalan, Bunara, and finally at Rohua. But all of these - with the exception of Hahuwalan - eventually became multi-clan villages. This has had radical implications for land relations in general and has given rise to some contradiction in interpreting the rules, aggravated by pressure on land [Ellen, 1977 : 59]. There has been, therefore, a greater conscious identity generated between groups and individual plots. In coming to the coast much ancestral land was neglected, except that of those clans with traditional claims to land on which most Nuaulu gardens in the Sepa area are now situated. There was a dislocation in the hitherto enduring connection between clan and land. This situation, together with the movement of land between clans following marriage, has meant that the lineal continuity of association between a clan and a particular area of land was broken;

2. cash-cropping, particularly of cloves and coconut, but also of coffee, quickly followed daily contact with the market economy which coastal settlement made possible. This has led to rules relating to land increasingly resembling those relating to other kinds of property. Traditionally, swiddens were cleared, cultivated and re-absorbed into the forest, leaving traces only in the form of small groves of valued trees, such as Areca palms. But the relationship between people and land was still regarded as highly personal, being likened to that between a father and children. As a father is responsible to the ancestors for his children, so is the group for the land. With permanent or semipermanent groves, the human effort going into the transformation of the forest and maintenance of the land became continuous and hence the particular relationship became more enduring and intensive;

3. prior claims by Sepa, and by other long-estahlished coastal villages, to accessible garden land, and increasing demand for land arising from cash-cropping and population growth had, by the early seventies, for the first time, turned land into a scarce resource. Scarcity provided an incentive to maintain relations with land over long periods of time, which resulted in a greater emphasis on clear-cut, unambiguous, jural relations with land held in perpetuity. This has inevitably become a source of conflict hetween clans, villages, and particularly between Nuaulu and non-Nuaulu in Sepa and Tamilou. Disputes increased during the seventies and eighties, as pressure on land and other resources has become more acute, due to yet more cash-cropping, indigenous population growth, in-migration and land sale. The situation has been further exacerbated by the lag in revising rules and practices relating to land tenure, amongst the most important of which has been 
failure to establish clear boundaries between wasi:;

4. in the early seventies sale of land was still a relatively novel concept [Ellen, 1977: 63]. No one could remember a Nuaulu ever having acquired land from Sepa since the first gift of land made by Raja Kamari Kaihatu Tihurua around 1870 , which established the physical villages of Watane, Aihisuru, Bunara and Hahuwalan; and only one other instance of sale of land in Rohua could be recalled. However, in 1968 Merpati Sonawe of Watane had bought some garden land from Sepa for 9,000 Indonesian rupiahs, and during February 1970, Utapina Kamama of Bunara bought some land from Sepa as a means of obtaining some level ground for a coconut grove. But despite the rarity of actual sale, the concept of land as an exchangeable commodity was wellestablished by 1970 [Ibid., 63-4];

5. although attitudes to land are being increasingly moulded by a market model, individual transactions still involve a customary element. Thus, in 1990 during my visit to Simalouw, the main Nuaulu settlement in the Ruatan transmigration zone, Merpati was engaged in setting-out the terms of a sale for some new settlers at Kilo 7 for approval by the local District Officer. The asking «price» on this occasion was : five piruna batu (lit. «stone plates»; that is old porcelain, though not necessarily oriental in origin), five meters of red cloth and 10,000 rupiahs for each household head. This is a global payment to the Nuaulu negotiated on their behalf by Merpati at the time of my visit.

\section{Population growth and transmigration, 1970-1990}

During the period covered by my own fieldwork Nuaulu population has continued to grow dramatically (see table), despite some fall-away due to religious conversion. This has led to greater pressure on existing land, intensified by competition along the south Seram littoral with people from tra-
Nuaulu population

growth in relation

sub-district population,

1971-1990

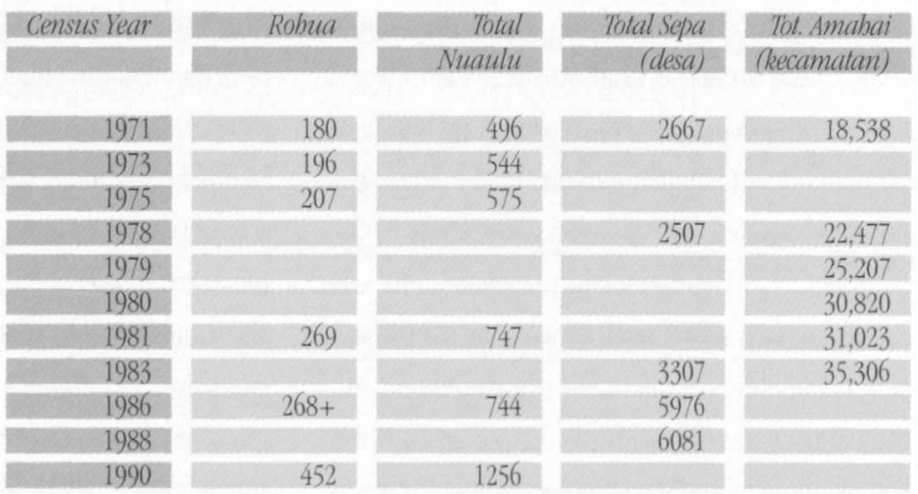

Note

For the basis of figures listed in columns 2 and 3 see footnote 2 . The Sepa figure for 1971 (based on 1970 data) was provided by the Kantor Sensus dan Statisik, Dati II, Maluku Tengah, Masohi. The remaining sources are: Amahai 1971 [Kantor Sensus dan Statistik Propinsi Maluku, 1972]; Amahai 1978, Sepa 1978 [Kantor Sensus dan Statistik Propinsi Maluku, 1980]; Amahai 1979 1981, 1983 , Sepa 1983 [Kantor Kecamatan Amahai, 1983]; Amahai 1980 [Kantor Sensus Propinsi Maluku, 1980]; Sepa 1986, 1988 [unpublished figures in Kantor Camat, Amahai, $1990]$. 
ditional non-Nuaulu villages, and due to unplanned immigration, mainly of Butonese. Prior to this there had been the arrival of a few Chinese and Buginese traders, but these have hardly amounted to much; and some re-settlement from AmbonLease, internal relocations (Yalahatan, Rutah), and of course some growth of the administrative post at Amahai. Growth along the south coast was facilitated by extension of a metalled road during the early eighties.

At about the same time the government began to establish transmigration settlements along the Ruatan valley ${ }^{[4]}$. The government recugnized uncut forest in the vicinity as belonging to the Nuaulu and encouraged them to move into one of the new settlements at Simalouw. Many saw this as a return to traditional land and although by 1990 only the villages of Watane and Aihisuru had moved permanently, many Nuaulu established temporary dwellings, used the improved transport facilities to reach ancestral sago areas and began to cut land for cash crop plantations. Implicit government recognition of Nuaulu preferential rights to over one-and-a-half thousand square kilometres ${ }^{[5]}$ enabled them to sell land to other incomers. This alleviated the growing pressure on Nuaulu land generally and permitted them also to sell land along the more crowded south coast around Sepa, most of which has gone to Sepa itself and to incoming Butonese. As I have argued elsewhere [Fllen, 1993b], this created a rarely reported situation whereby an indigenous forest people appeared to be endorsing further forest destruction, by themselves and by others, for short-term gain. Moreover, the practices which accompanied this were not dramati- cally contrary to any locally-asserted principles of indigenous ecological wisdom [Ellen, 1986]. However, there has been increased conflict with other autochthonous villages over rights to land and, since 1990, disenchantement with the effects of logging and serious conflict with settlers resulting in convictions for murder being brought against three residents of Rohua. Thus, the possibilities for re-creating some aspects of traditional social life and intensifying others, paradoxically through sale of land and other resources to outsiders, is undermining the very system the protagonists seek to preserve.

\section{DISCUSSIOK}

In this paper I have tried to make sense of the small amount of data available on the ecological and human consequences of deforestation in the Moluccas, and human responses to this. I have supplemented the brief reports we have from most places with one case-study, that of the Nuaulu, which summarizes what I have published elsewhere. The Nuaulu case may well be atypical, but it is at least indicative in several general ways.

Firstly, it enables us to look at a case where deforestation arises from a number of interacting forces : intensification of subsistence ayriculture, cash-cropping, forest extraction, logging and transmigration. The commercial lumber industry has grown remarkably over the last three decades, but the main threat to the livelihoods of those people dependent on the forest, and to the future of the forest itself, comes from Indonesian government transmigration policy.

Secondly, the Nuaulu case shows how the form, rates and consequences of deforestation 
change over time; and that when we assess the advantages and disadvantages to local populations, these must be related to different stages in a process. I note that the initial response to some forms of forest destruction and consequent land settlement may often be viewed positively by indigenous peoples, the situation offering opportunities to sustain, and indeed intensify, existing patterns of subsistence and other cultural practices. I further suggest that an eventual realization of the follow-through consequences leads to a middle phase of uncertainty, which may eventually translate into intense hostility to incomers and to any additional destruction of forest. This final stage is fast approaching for the Nuaulu, and in the Maneo area it should be expected that villages might act decisively to defend territorial interests were they to be faced with comparable challenges. Of course, not all local groups are in a position to resort to such measures, and locally patterns of response must be expected to vary.

Thirdly, the Nuaulu case reminds us that interpretations of the law vary depending on local considerations, as well as political and bureaucratic purposes. In theory, the Indonesian government continues to maintain a fundamental assertion of the Basic Agrarian Iaw (Undang-Undang Pokok Agraria) of 1960, namely that state law is based on adat (customary) law [SKEPHI \& Kiddell-Monroe, $1993: 236-7]$. But the law is internally contradictory, as are the goals and interests of different government departments. The result is confusion. Officially, adat claims to historic areas of forest have no bearing on the selection of transmigration areas [MacAndrews, 1986], and certainly the government does not officially enter- tain compensation. But as we have seen, in the Ruatan scheme, Nuaulu and other indigenes were permitted to benefit by selling land to transmigrants, and by releasing land to the government in exchange for houses and other facilities. The Basic Forestry Law of 1967 recognizes social, traditional and individual rights, but does not permit their expression to interfere with the goals of the law, one of which is the production of forest commodities. Other special forestry laws override the Basic Agrarian Law, criminalizing certain kinds of forest use by indigenous populations [Colchester, 1993 : 75]. Thus, in 1971 the Forestry Department designated Yamdena a protected area, and ten years later created a 60,000 hectares nature reserve with UNDP/FAO backing, only to later issue a decree establishing a logging concession in the area of the reserve. Such overlapping of decrees is common in Indonesia [SKEPHI, 1992 : 24; see also Hurst, $1990: 10-2]$. In practice, whatever the legal position, the state has the authority to regulate and implement the allocation, use, supply, and care of all resources, placing the national interest above that of the individual [Hardjono, 1991 : 9]. But in certain areas traditional patterns of access still prevail. Occasionally, compromise has been possible, but even if initial prospects seem promising conflict of some kind is predictable eventually.

Fourthly, the Nuaulu case illustrates clearly that the increased cutting of mature forest was only possible through new government assisted infrastructures and incentives, and that land cut is for the establishment of plantation crops not to supplement subsistence swiddening needs. Nuaulu sell land because settlers ask for it, and 
because the government expects them to do so. There is certainly a financial inducement, though as we have seen, land transfers are still partly a matter of customary ritual compensation. The material spin-off has so far proved to be fairly short-lived, and its distribution the cause of internal disputes. The benefits to the Nuaulu from selling non-timber forest products is minimal, raising little hope for sustained non-destructive extraction and income-raising [Dove, $1993: 17$, citing Shaw et al.]. This is consistent with Dove's observation [Ihid, p.21] that forest peoples do not appear to degrade forests because they are poor, but because they are impoverished by the degradation of their forests by external forces which they are too weak to control.

We have long known that ideology and cosmology are poor indicators of practice, and now know that claims for the existence of balanced ecologically self-sustaining rainforest economies are ethnographically difficult to demonstrate. Some peoples, measurably, do not degrade their environment in any obvious way; but this is often less «adaptation" (in the sense of an outcome of various selective pressures, or of a particular ethos) than a benign consequence a specified social organization, demographic structure and pattern of subsistence geared to investment in environmental resources which replenish themselves through relatively short cycles. What is critical is to maintain population at a level which never threatens the carrying capacity of a system, even if it alters it. To this end, the use of broad spectrum subsistence strategies reduces stress on particular resources, patches and time-phases, and the degree of isolation from other systems.
The greater the degree of isolation, the more effective control over resources. Both isolation and low population are properties of a system which has the mechanical effect of making regulation simpler and more reliable; relative autonomy increasing the probability of effective regulation consciously or inadvertently. The varied ecologies of different Moluccan peoples well illustrate these features in relation to an interconnected rainforest and maritime system. The Moluccas also provide us with a conveniently long historical timedepth in which to observe the break-down and transformation of locally autonomous patterns of subsistence. Developments over the last 20 years, however, have accelerated exponentially long term processes in a way which endanger the survival of both remaining sustainable extractive regimes and the forest itself. 


\section{ACHNOWLEEGEMENTS}

The Nuaulu fieldwork on which part of this paper is based was conducted under the auspices of the Indonesian Academy of Sciences in 1969-71. 1973, 1975, 1981, 1986 and 1990; a period of 24 months all told. The research has been supported, on different occasions by the ESRC, the Hayter Travel Scheme, and the University of Kent. My personal indebtedness to the Nuaulu in relation to the particular matters described here is recorded in full in Ellen 1993b. I am additionally grateful to the following individuals for augmenting my knowledge of current developments (especially in other parts of the Moluccas) :

Rosemary Bolton, Ian Edwards, Jorl Goss, Jim Hagen, Christopher Healey, Alistair Macdonald and leontine Visser. Of course, I alone am responsible for the final views expressed. and for the accuracy of the information as printed. Writing support was made possible by receipt of an FSRC research grant (R.000).23.3088) for the period 1991-94. 


\section{EHDNOTES}

\section{1}

In this and subseguent sections ! have taken an essentially phytocentric view of rainforest, and have little to say about faunal depletion or modification. It is, however, widely recognized that Moluccan avifauna in particular is under threat [see Ellen, 1993b: 199. 201]. [ have also ignored the impact of industrial development. 'This is beculse, at present, such factors are of limited relevance. However. crude oil has been extracted from wells on Seran since 1917, mainly in the vicinity of Bula. The area around Bula has, consequently, long been an environmental mess. Much more recently, work has begun on a factory along the Wate lau in the Tehoru sub-district, the purpose of which will be to produce klinker for cement mantfacure. This is likely to require large quantities of water, generate alkaline dust and pollute streams with consequences for riverside and estuarine biota. It will atso involve removal of timber for construction and roads, and make claims on indigenous territories for mines. The exact human and envirommental results of this are presently unclear, though the prognosis is depressing.

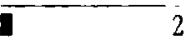

Agatbis has even been planted in places for the commercial extraction of dammar [Ormeling, 1947]. 3

In table l, columin I provides the years during which I conducted my own initial census and subsequent updates. The 1970 census was complete and reliable, but on subsequent visits I have only updated census data for Rohua. Even here the figures must be understood as provisional and errors may occur due to under-reporting of infant mortality in particular, the common practice of name-changing and shifts in residence between villages. The Rohua figures are designed to include all ethmic Nuaulu, including Christian and Muslim converts who remain in the village, any non-Nuaulu spouses, and their joint offspring. They do not include other in-migrants. In 1971 the population of Rolula was 36 percent of the Nuaulu total and I lyave assumed for the purpose of calculating the total figures for 1973 through to 1990 thit this has continued to be approximately the case. There are no separate official statistics for ethnic Nuaulu, and occasionally available figures for animists in the sub-district as a whole have to he treated with extrenc caution; electoral figures available for 1986 refer only to adults and do not discriminale between Nuaulu and non-Nuaulu.

The Sepa figure for 1971 (based on 1970 data) was provided by the Kantor Sensus dan Statistik, Dati II, Maluku Tengah, Masohi.

The remaining sources are: Amahai 1971 [Kantor Sensus dan Statistik Propinsi Maluku, 1972]; Amahai 1978, Sepa 1978 [Kantor Sensus dan Statistik Propinsi Maluku. 1980] Anlahai 1979, 1981, 1983, Sepa 1983 [Kantor Kecamatan Amahai, 1983]; Anlahai 1980 [Kantor Sensus Propinsi Maluku,1980]; Sepa 1986, 1988 | unpublished figures in Kantor Camal, Arahai, 1990].

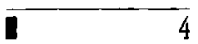

Seram did not effectively featuro in the transmigration progranme until the second half of the seventies (see above), with the arrival of 400 families in the Kairatu area. The first official (as opposed to independent or spontaneous) scttlenent of this kind in South Seram was at letwaru in 1964, and comprised some 60 houselrolds from Serua. By 1976 , the Ruatan valley sonne two kilometres up-river from Makariki was beginning to receive its first official settles ( 50 households in 1976, and the same again in 1977). In 1979 the government moved in a massive 1,175 households into the Wae Pia area, and in 1982 another 90-150 households [Kantor Statistik Kabupaten Maluku Tengah, 1984: 115]. However, the most spectacular project, if not the largest in terms of actual numbers, was the wholesale removal of the sub-district of Teon, Nila and Serua (a small group of istands some 300 kilometres to the south) to the Wase Siru area on the Nua, which in 1983 (just before resettlement) had a population of 6.421 [Kantor Statistik Kabupaten Maluku Tengah, 1983:24\}.

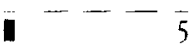

The official land area of Amahai sub-district is 2,070.28, and the shoreline in excess of 80 kilometres. The figure provided is obtained if we multiply the length of coastline by the 5 kilometres accepted by Nuaulu and government alike as that distance from the coast beyond which all land nust be regarded as the legal entitlement of the Nualulu, and subtract this from the official area. The area left includes part of the Manusela (Wae Mual) National Park, a forest reserve of some 186,000 hectares and in which settlement is officially prohibited. There is evidence for a similar benign goverument attitude lowards indigenous rights from Seti and some closeby villages along the north coast of Seram, where people ruportedly enjoy aexclusive" rights to ancestral land. 